PACS 68.43

\title{
ADSORPTION EQUILIBRIUM AND HYSTERESIS IN OPEN SLIT-LIKE MICROPORES
}

\author{
Kutarov V.V. ${ }^{1}$, Tarasevich Yu.I. ${ }^{2}$, Aksenenko E.V. ${ }^{2}$, Dlubovskiy R.M. ${ }^{1}$ \\ ${ }^{1}$ I.I. Mechnikov National University of Odesa, Research Institute of Physics \\ 27 Paster Str., Odesa, 65082, Ukraine \\ ${ }^{2}$ Dumanskii Institute of Colloid and Water Chemistry of National Academy of Sciences of Ukraine \\ 42 Vernadsky Blvd., Kyiv, 03142, Ukraine
}

For qualitative and quantitative description of adsorption equilibrium and hysteresis in open slit-like micropores, theoretically rigorous equations are proposed based on the theory of volume filling of micropores which imply the physical and formal analogy between the volume filling of micropores and capillary condensation. The applicability of the proposed equations for description of the hysteresis in such systems is demonstrated for water adsorption/desorption isotherm on the fibrous carbon material AUVM-Dnepr which possesses micro- and mesoporous structure.

Keywords: adsorption, hysteresis, slit-like pores, carbon material, porous bodies

\section{INTRODUCTION}

In the general case of porous bodies which possess micro- and mesopores, the adsorption should be considered as a stage-by-stage process. Within pore range with a characteristic size lower than the adsorbate molecular diameter $\sigma$, the adsorption occurs on the external surface. If the characteristic size of the slit-like pore, i.e. the ratio of the pore width to the adsorbate molecular diameter is in the range $1<\mathrm{h} / \sigma<2$, then the adsorption process is governed both by the interaction between the adsorbate molecules and by the interaction of adsorbate molecules with the force field of very narrow pore, having in mind the overlapping of the pore walls potential. For the pores with characteristic size above $2 \sigma$ filmwise condensation occurs [1].

The irreversibility of the adsorption process in porous bodies, which results in adsorption hysteresis, also should be considered with regard to the characteristic size of the porous space. If the pore width $h>5 \sigma$, then the hysteresis description should assume the filmwise condensation and capillary evaporation process, governed by the Kelvin equation $[1,2]$. On the other hand, if the pore width is in the range $\sigma<\mathrm{h}<2 \sigma$, the adsorption process should be treated according to the theory of volume filling of micropores (TVFM) [1]; in this case the adsorption hysteresis is caused by the 'memory effect' of the adsorption system $[1,3]$. The adsorption hysteresis theory based on

* corresponding author thomascat@voliacable.com ХФТП 2013. T. 4. № 4
TVFM was developed in [3]. It should be noted that, while the scope of the publications related to the adsorption hysteresis theory is vast, these refer to the hysteresis in mesopores, while the adsorption hysteresis in micropores was studied only experimentally. The authors are unaware of any theoretical publications in this specific field.

It was reported recently by one of the authors in [4] that the classic TVFM equations do not correspond exactly to the basic TVFM principle, and a new equation was proposed to describe the volume filling of cylindrical pore. In the proposed study the approach developed in [4] is presented in more detail (having in mind that the short publication [4] is quite hard-to-reach), and is applied to the description of the adsorption equilibrium and hysteresis in a slit-like pore.

\section{THEORY}

To begin with, we recapitulate some statements considered in [4]. The TVFM developed by Dubinin [5] and (independently) by Pierce, Wiley and Smith [6] was based on the assumption that the adsorption in the pores should be treated as their volume filling (similar to the capillary condensation process) rather than their layer-by-layer filling. The physical analogy between both processes implies their formal analogy, i.e. the volume filling of pores and the capillary condensation could be expected to obey similar mathematic treatment. 
All the TVFM equations currently used were derived on the basis of the Polanyi theory $[1,7]$. The adsorption isotherm equation proposed here is also based on the Polanyi's characteristic curve [7]:

$$
\theta=f(\beta \mathrm{A}) \text {, }
$$

where, according to the TVFM, $\theta$ is the relative coverage, i.e. the ratio of the current adsorption value to its maximum possible value which corresponds to the rightmost boundary of the micropores range; note that $\theta<1$. In Eq. (2) A is the Polanyi adsorption potential which by its physical meaning determines the variation of Gibbs potential during the adsorption: $\mathrm{A}=-\Delta \mathrm{G}$ :

$$
\mathrm{A}=\mathrm{RT} \ln \left(\mathrm{p}_{0} / \mathrm{p}\right)
$$

where $\mathrm{p}$ and $\mathrm{p}_{0}$ are the adsorbate pressure in the bulk phase and the saturation pressure, correspondingly, at temperature $\mathrm{T} ; \beta$ is the affinity parameter as introduced by Dubinin [8], $\mathrm{R}$ is the universal gas constant.

Various adsorption isotherm equations (Dubinin-Radushkevich [9], Dubinin-Astakhov $[10,11]$, Dubinin-Stoeckli $[8,12])$ can be obtained based on the characteristic curve, using the equation of the thermodynamic perturbation theory for polymolecular adsorption, see [7, 13, 14]:

$$
\theta_{\mathrm{n}}=\int_{\mathrm{A}}^{\infty} f\left(\varepsilon_{\mathrm{k}}\right) \mathrm{d} \varepsilon_{\mathrm{k}},
$$

where $\theta_{\mathrm{n}}$ is the $\mathrm{n}$-th layer relative coverage, $\varepsilon_{\mathrm{k}}$ is the local value of the pore wall potential, $f\left(\varepsilon_{\mathrm{k}}\right)$ is the fraction of adsorption space which corresponds to this $\varepsilon_{\mathrm{k}}$ value. The total coverage then is:

$$
\theta=\sum_{\mathrm{n}=1}^{\infty} \theta_{\mathrm{n}}
$$

Equations (3) and (4) were used mostly to describe the polymolecular adsorption. However, assuming $\theta_{\mathrm{n}}=0$ for all $\mathrm{n}>1$, the integration in Eq. (4) with the modified Gaussian distribution for $f\left(\varepsilon_{\mathrm{k}}\right)$ yields the Dubinin-Radushkevich equation $[8,13]$. If the Weibull-Gnedenko distribution is chosen for $f\left(\varepsilon_{\mathrm{k}}\right)$, then the integration in Eq. (4) results in the Dubinin-Astakhov adsorption isotherm [1].

It should be stressed here that the Polanyi theory [7], upon which all presently known TVFM equations essentially rely, is in fact the special case of the Gibbs surface thermodynamics [7].
Therefore, the theoretical approach on which the TVFM adsorption isotherm is based, does not involve the basic postulate of TVFM about the analogy between the volume filling and capillary condensation.

For the pore width range $\sigma<\mathrm{h}<2 \sigma$, the quasione-dimensional phase (molecular associate, cluster which does not exhibit any surface tension) is formed in the pore.

The capillary evaporation process is described by the Kelvin equation $[1,2]$ :

$$
\mathrm{x}=\frac{\mathrm{p}}{\mathrm{p}_{0}}=\exp \left(-\frac{\gamma \mathrm{V}_{1}}{\mathrm{RTt}_{\mathrm{k}}}\right) \text {. }
$$

Here $\gamma$ and $V_{1}$ are the surface tension and molar volume of liquid adsorbate; $t_{k}$ is the core width, which is the difference between the pore width and the thickness of the condensate film on the pore walls [1]. The governing parameter in Eq. (5) is the surface energy $\gamma$, which for the molecular associate could be zero or even negative [15].

The molecular theory of spherical drops in vapor phase was developed by Yu. Tovbin [15]. In particular, the expression analogous to the Kelvin's equation was proposed where the governing parameter $\varphi$ is the molecular associate energy in the potential field of pore walls. For the slit-like pores the equation derived in [15] becomes:

$\mathrm{x}=\frac{\mathrm{p}}{\mathrm{p}_{0}}=\exp \left(-\frac{\varphi \mathrm{z}_{0}}{\mathrm{RTh}}\right)$

where $\mathrm{h}$ is the pore width. In [15] the parameter $\mathrm{z}_{0}$ is rigorously determined analytically; however, in practical applications its calculation is too complicated. On the other hand, within the transition region thermodynamics for lowmolecular substances [15-17] the approximation $\mathrm{z}_{0} / \mathrm{h} \approx \sigma / \mathrm{h}=\theta$ provides reasonable accuracy.

The potential energy of molecular associate $\varphi$ in very thin pores was theoretically studied in $[18,19]$. In particular, the ratio of the potential energy of molecular associate in a slit-like pore to the potential energy of molecules relative to their interaction with open plane surface $\varphi_{0}$ was calculated in [20]; this dependence plotted $v s \mathrm{~h} / \sigma$ is shown by solid curve in Fig. 1. It is seen that the influence of the overlapping potentials created by the opposite walls remains essential even for slitlike pore width of $1.5 \sigma$. The potential function shown in Fig. 1 was analytically approximated in [20] using the Kirkwood-Muller formula; however, 
as was mentioned in [4], it could be deduced that for practical calculations a simpler dependence shown in Figure 1 by dashed curve:

$$
\bar{\varphi}=\frac{\varphi}{\varphi_{0}}=\frac{\mathrm{h} / \sigma}{-\mathrm{m}+\mathrm{h} / \sigma}
$$

provides a good approximation (with maximum relative error $\pm \delta=5.5 \%$ ) within the relative pore width range $1<\mathrm{h} / \sigma<2$. Here

$$
\mathrm{m}=1-\left(\frac{\varphi_{0}}{\varphi}\right)_{\mathrm{h} / \sigma \rightarrow 1} \text {. }
$$

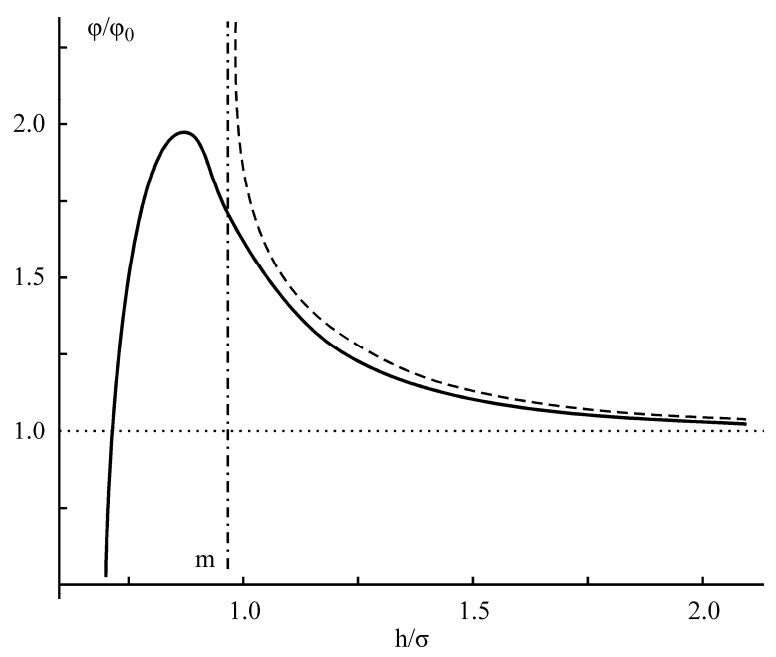

Fig. 1. The excess of the potential energy of adsorbate molecules in a pore $\varphi$ with respect to the potential energy of molecules over the infinite plane $\varphi_{0} v s$ the relative pore size $\mathrm{h} / \sigma$ (solid curve). Also shown are: the analytical approximation, Eq. (7) (dashed curve); the schematic asymptotic of this analytical approximation at $(\mathrm{h} / \sigma) \rightarrow \mathrm{m}$ (vertical dashdotted line); and the asymptotic at high $\mathrm{h} / \sigma$ (horizontal dotted line)

In what follows, the assumption commonly adopted in the adsorption theory is used: the relative pore width $h / \sigma$ is taken equal (within the accuracy sufficient for practical calculations) to the pore filling value $\theta$ [1], i.e. to the ratio of the current adsorption value to its value which corresponds to monolayer formation. This definition of $\theta$ is more reliable than that adopted in TVFM, because the rightmost boundary of the micropores range cannot be precisely determined due to the fact that a quite large transition range exists between the micropore and mesopore regions. Then Eq. (7) becomes:

$$
\bar{\varphi}=\frac{\theta}{-m+\theta} .
$$

The solution of combined Eqs. (7) and (9) with respect to $\theta$ yields:

$$
\theta=\mathrm{m}-\frac{\varphi_{0}}{\mathrm{RT} \ln \mathrm{x}} .
$$

Introducing the adsorption potential $A=R T \cdot \ln (1 / x)$, one obtains from Eq. (10):

$\theta=\mathrm{m}+\frac{\mathrm{A}_{0}}{\mathrm{~A}}$.

Here $\mathrm{A}_{0}$ is the adsorption potential corresponding to the relative pore range where the influence of the opposite pore walls becomes negligibly small, i.e. $\mathrm{A}_{0} / \mathrm{RT}=\varphi_{0} / \mathrm{RT}=-\ln \left(\mathrm{x}_{0}\right)$, where $\mathrm{x}_{0}$ is the relative pressure at which $\bar{\varphi} \rightarrow 1$. Therefore, Eq. (11) is obtained here in the framework of the basic TVFM postulate.

Comparing Eq. (8) and Fig. 1 one can see that the $\mathrm{m}$ value is approximately equal to 1 . However, in practical calculations it is more convenient to determine the parameters in Eq. (11) from the analysis of the specific isotherm considered.

Next we apply Eq. (11) to describe the adsorption hysteresis in a quasi-one-dimensional pore. The adsorption hysteresis is defined as the difference between the adsorption potential values at the direct and reverse branches of the hysteresis loop at the same value of adsorption value considered as the process coordinate.

From Eq. (11), the expressions for the process coordinates of adsorption $\mathrm{a}^{(\mathrm{a})}$ and desorption $\mathrm{a}^{(\mathrm{d})}$ follow:

$$
\begin{aligned}
& a^{(a)}=a_{m}^{(a)} \theta=a_{m}^{(a)}\left(m^{(a)}+\frac{A_{0}^{(a)}}{A^{(a)}}\right), \\
& a^{(d)}=a_{m}^{(d)} \theta=a_{m}^{(d)}\left(m^{(d)}+\frac{A_{0}^{(d)}}{A^{(d)}}\right) .
\end{aligned}
$$

In what follows, the superscripts (a) and (d) refer to the process parameters for the adsorption and desorption hysteresis branches, respectively; in Eqs. (12) and (13) the values $\mathrm{a}_{\mathrm{m}}^{(\mathrm{a})}$ and $\mathrm{a}_{\mathrm{m}}^{(\mathrm{d})}$ are the maximum adsorption values for the adsorption and desorption, respectively. Then the adsorption potential at the desorption branch of the hysteresis loop for equal coordinates of the adsorption and desorption processes is: 


$$
\mathrm{A}^{(\mathrm{d})}=\mathrm{A}_{0}^{(\mathrm{d})}\left[\frac{\mathrm{a}_{\mathrm{m}}^{(\mathrm{a})}}{\mathrm{a}_{\mathrm{m}}^{(\mathrm{d})}}\left(\mathrm{m}^{(\mathrm{a})}+\frac{\mathrm{A}_{0}^{(\mathrm{a})}}{\mathrm{A}^{(\mathrm{a})}}\right)-\mathrm{m}^{(\mathrm{d})}\right]^{-1}
$$

and the adsorbate relative pressure in the bulk phase for the desorption branch of the hysteresis loop $\mathrm{x}^{(\mathrm{d})}$ is given by the expression:

$$
\mathrm{x}^{(\mathrm{d})}=\exp \left\{-\frac{\mathrm{A}_{0}^{(\mathrm{d})}}{\mathrm{RT}}\left[\frac{\mathrm{a}_{\mathrm{m}}^{(\mathrm{a})}}{\mathrm{a}_{\mathrm{m}}^{(\mathrm{d})}}\left(\mathrm{m}^{(\mathrm{a})}+\frac{\mathrm{A}_{0}^{(\mathrm{a})}}{\mathrm{A}^{(\mathrm{a})}}\right)-\mathrm{m}^{(\mathrm{d})}\right]^{-1}\right\} \text {. }
$$

In what follows, Eqs. (12) and (15) are used to describe the adsorption equilibrium and hysteresis in open slit-like micropores.

\section{EXPERIMENTAL RESULTS AND DISCUSSION}

Isotherms of water vapor adsorption on fibrous carbon materials were reported in several publications, see e. g. [21]. In this study, the water vapor adsorption/desorption isotherm on the fibrous carbon material AUVM-Dnepr (AУBMДнепр) which possesses micro-mesoporous structure in which the slit-like and cylindrical micropores prevail. The physicochemical characteristics of the material are extensively summarized in [22]; in particular, the specific surface area (BET) is $1375-1680 \mathrm{~m}^{2} / \mathrm{g}$, the micro-, meso- and macroporous volumes are $0.26,1.17$ and $0.44 \mathrm{~cm}^{3} / \mathrm{g}$, respectively. The isotherms were measured by the authors using the vacuum adsorption device with McBain-Bakr quartz helix balance at $\mathrm{T}=294.15 \mathrm{~K}$ [23].

The initial analysis of the isotherm shown in Fig. 2 by its fitting to the BET equation [1] yields the monolayer adsorption value $\mathrm{a}_{\mathrm{m}}^{(\mathrm{a})}=3.85 \mathrm{mmol} / \mathrm{g}$. Therefore, even at $\mathrm{x} \rightarrow 1.0$ the coverage value $\theta<1.9$, and therefore the adsorption process within the range $0.1<\mathrm{x}<1$ obeys the volume filling mechanism.

To apply Eq. (11) for the description of the adsorption isotherm, the isotherm was re-plotted in the coordinates $\theta^{(\mathrm{a})}=f\left(\mathrm{~A}^{(\mathrm{a})}\right)^{-1}$. The result is shown in Fig. 3; it is seen that the isotherm consists of two straight intervals. For the first interval the parameters (the $\mathrm{m}$ value and the slope) were obtained using the standard procedure; it was found that (to within the experimental error) $m=1$. From Fig. 3, an interesting feature of the quasi-onedimensional adsorption regime becomes obvious: for low adsorbate density in the bulk the adsorbate in the pore exists as the molecular associate, while with the increase of the bulk adsorbate density above the value which corresponds to $\mathrm{x}=0.9$ clusterisation of the associate takes place. This behaviour resembles the transition from gaseous phase to condensed phase; however, any exact analogy with the phase transition cannot be drawn because the one-dimensional system is incapable to undergo any phase transition [24].

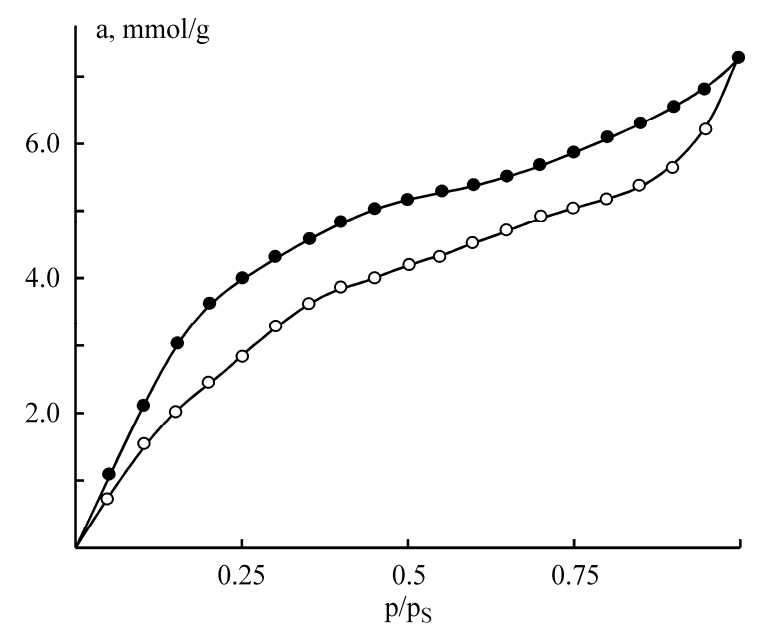

Fig. 2. The adsorption (o)/desorption (•) isotherm for water vapors on the fibrous carbon material AUVM-Dnepr

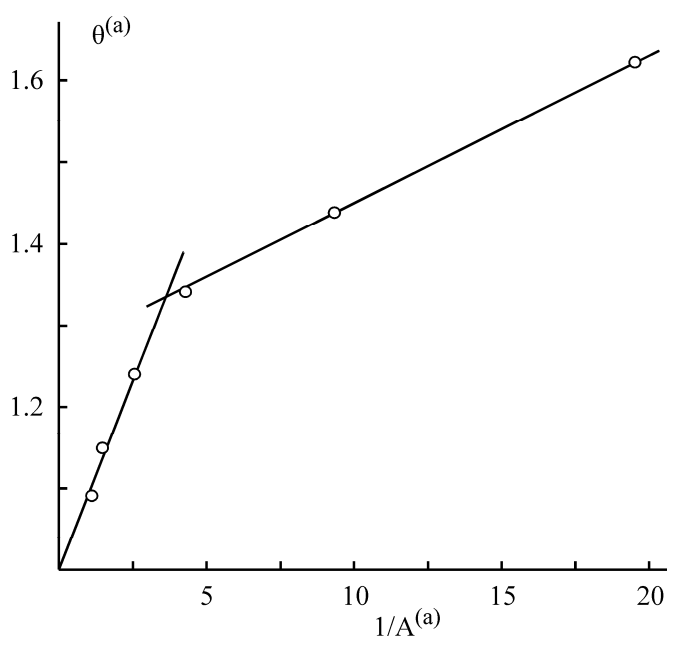

Fig. 3. The water vapor adsorption isotherm on fibrous carbon material AUVM-Dnepr plotted in the coordinates $\theta^{(\mathrm{a})}=f\left(\mathrm{~A}^{(\mathrm{a})}\right)^{-1}$

It was noted above that the adsorption process is characterised by two stages with different process parameters. Assuming the decreasing power function as the approximation, one obtains for the adsorption isotherm equation:

$\theta^{(\mathrm{a})}=1+\left(\frac{\mathrm{A}_{0}^{(\mathrm{a})}}{\mathrm{A}^{(\mathrm{a})}}\right)^{\alpha_{1}}$, 
where the values $\mathrm{A}_{0}^{(\mathrm{a})}=0.032 \mathrm{RT}, \alpha_{1}=0.68$ were obtained from the fitting. With these parameters, Eq. (16) describes the adsorption isotherm shown in Fig. 2 to within the maximum relative deviation $\pm \delta=7.5 \%$.

Next the desorption isotherm was analysed. The monolayer adsorption as determined from BET equation is $\mathrm{a}_{\mathrm{m}}^{(\mathrm{d})}=4.28 \mathrm{mmol} / \mathrm{g}$. In Fig. 4 the desorption isotherm re-plotted in the coordinates $\theta^{(\mathrm{d})}=f\left(\mathrm{~A}^{(\mathrm{d})}\right)^{-1}$ is shown; it is seen that the desorption process also takes place in stages. However, it is obvious from the adsorption/desorption isotherm plot that for the calculation of the hysteresis loop only the range $0.4<\mathrm{x}<0.9$ is relevant. Similarly to the adsorption process, the equation for the desorption branch in the framework of the formalism involved in Eq. (12) should read:

$\theta^{(\mathrm{d})}=1+\left(\frac{0.06 \cdot \mathrm{RT}}{\mathrm{A}^{(\mathrm{d})}}\right)$.

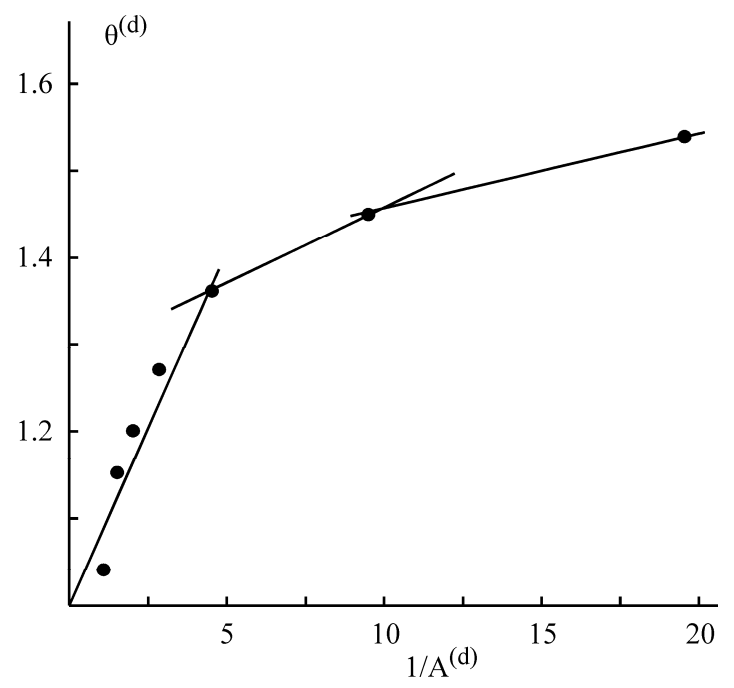

Fig. 4. The water vapor desorption isotherm on fibrous carbon material AUVM-Dnepr plotted in the coordinates $\theta^{(\mathrm{d})}=f\left(\mathrm{~A}^{(\mathrm{d})}\right)^{-1}$

Eq. (17) describes the desorption branch of the hysteresis loop in the range $0.4<\mathrm{x}<0.9$ with maximum relative error $\pm \delta=5.7 \%$.

To calculate the hysteresis loop, the expression for the relative adsorbate pressure in the bulk phase should be derived, in which the process coordinates should be equal to each other. Similarly to Eqs. (14) and (15), one obtains:
$\frac{\mathrm{A}_{0}^{(\mathrm{d})}}{\mathrm{A}^{(\mathrm{d})}}=\left\{\frac{\mathrm{a}_{\mathrm{m}}^{(\mathrm{a})}}{\mathrm{a}_{\mathrm{m}}^{(\mathrm{d})}}\left[1+\left(\frac{\mathrm{A}_{0}^{(\mathrm{a})}}{\mathrm{A}^{(\mathrm{a})}}\right)^{\alpha_{1}}\right]-1\right\}$

which yields the relation for the calculation of $\mathrm{x}^{(\mathrm{d})}$ value:

$$
x^{(d)}=\exp \left\{-A_{0}^{(d)}\left[\frac{a_{m}^{(a)}}{a_{m}^{(d)}}\left(1+\frac{A_{0}^{(a)}}{A^{(a)}}\right)^{\alpha_{1}}-1\right]^{-1}\right\} .
$$

In Fig. 5 the values $\mathrm{x}_{\text {calc }}^{(\mathrm{d})}$ calculated from Eq. (19) are compared with the $x_{\exp }^{(d)}$ values determined from the experimental isotherm. This clearly demonstrates the validity of the proposed approach.

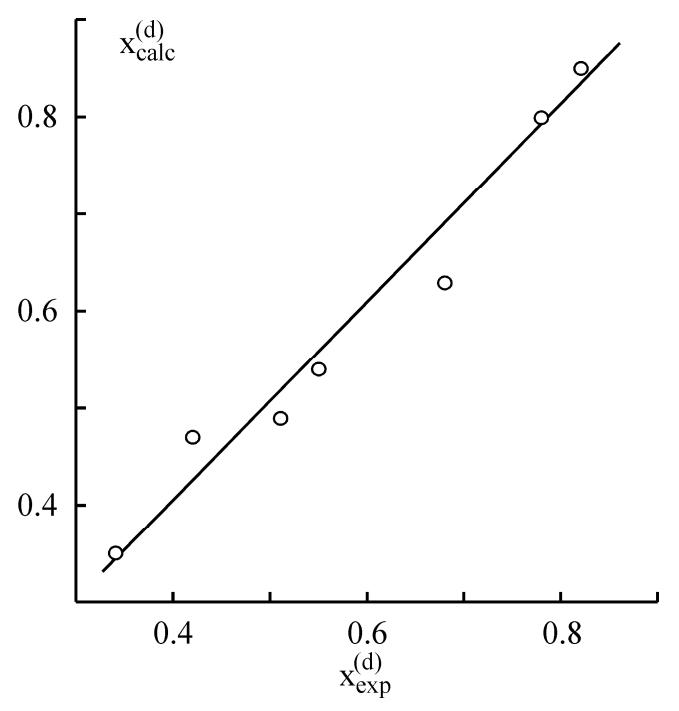

Fig. 5. The comparison of values $x_{\text {calc }}^{(d)}$ calculated from Eq. (19) (straight line) with $x_{\exp }^{(d)}$ values determined from the experimental isotherm (points)

\section{CONCLUSIONS}

Within the framework of the basic postulate involved in the TVFM, which implies the physical and formal analogy between the volume filling of micropores and the capillary condensation, the rigorous new equations are proposed for the description of adsorption equilibrium and hysteresis in open slit-like micropores. The applicability of the developed approach is demonstrated using the isotherm of water vapor adsorption/desorption on fibrous carbon material AUVM-Dnepr which possesses micro- and mesoporous structure. 


\title{
Адсорбційна рівновага і гістерезис у відкритих щілиноподібних мікропорах
}

\author{
Кутаров В.В., Тарасевич Ю.І., Аксененко Є.В., Длубовський Р.М.
}

Одеський національний університет ім. I.I. Мєчнікова, Науково-дослідний інститут фізики вул. Пастера, 27, Одеса, 65082, Україна

Інститут колоїдної хімї і хімї̈ води ім. А.В. Думанського Національної академії наук Украӥни бульв. Академіка Вернадського, 42, Київ, 03142, Украӥна, thomascat@voliacable.com

Для якісного $i$ кількісного опису адсорбційної рівноваги $i$ гістерезису у відкритих шілиноподібних мікропорах запропоновані теоретично строгі рівняння, засновані на постулаті теорії об'ємного заповнення мікропор щзодо фізичної $i$ формальної аналогії між процесами об'смного заповнення мікропор $і$ капілярною конденсацією. На прикладі ізотерми адсорбиіїдесорбиіі парів води волокнистим вуглецевим матеріалом АУВМ-Днепр, який має мікромезопористу структуру, показана придатність одержаних рівнянь для опису гістерезису в таких системах.

\section{Адсорбционное равновесие и гистерезис в открытых щелевидных микропорах}

\author{
Кутаров В.В., Тарасевич Ю.И., Аксененко Е.В., Длубовский Р.М.
}

Одесский национальный университет им. И.И. Мечникова, Научно-исследовательский институт физики ул. Пастера, 27, Одесса, 65082, Украина

Институт коллоидной химии и химии воды им. А.В. Думанского Наџиональной академии наук Украинь бульв. Академика Вернадского, 42, Киев, 03142, Украина, thomascat@voliacable.com

Для качественного и количественного описания адсорбиионного равновесия и гистерезиса в открытых щелевидных микропорах предложены теоретически строгие уравнения, основанные на постулате теории объемного заполнения микропор о физической и формальной аналогии между процессами объемного заполнения микропор и капиллярной конденсаџией. На примере изотермы адсорбции-десорбции паров воды волокнистым углеродным материалом АУВМ-Днепр, имеющим микро-мезопористую структуру, показана применимость полученных уравнений для описания гистерезиса в таких системах.

\section{REFERENCES}

1. Gregg S.J., Sing K.S.W. Adsorption, Surface Area and Porosity, Academic Press, London, $1982,303 \mathrm{p}$.

2. Thomson $W$., Sir. On the equilibrium of vapor at a curved surface of liquid, Philos. Mag., 42 (1871) 448.

3. Kutarov V.V., Robens E., Tarasevich Yu.I., Aksenenko E.V. Adsorption hysteresis at low relative pressures, Theor. Exp. Chem., 47 (2011) 163.

4. Kutarov V.V., Zub Yu.L., Shevchenko V.N. Adsorption equilibrium in open cylindrical micropores. In: Proc. XIII Ukrainian - Polish Symposium "Theoretical and Experimental
Studies of Interfacial Phenomena and their Technological Applications", (Sept. 11-14, 2012, Kyiv, Ukraine), 71.

5. Dubinin M.M., Zaverina E.D., Radushkevich L.V. Sorption and structure of active carbons, Zhurn. Fiz. Khimii (USSR), 21 (1947) 1351 (in Russian).

6. Pierce C., Wiley J.W., Smith R.N. Capillarity and surface area of charcoal, J. Phys. Chem., 53 (1948) 669.

7. Flood E.A. The Gibbs and Polanyi thermodynamic descriptions of adsorption "The Solid-Gas Interface, V. 1" / E.A. Flood, Ed., Marcel Dekker, NewYork, 1967, 11. 
8. Dubinin M.M. Contemporary state-of-the-art of the theory of volume filling of micropores for carbonaceous adsorbents, Izvestiya AN SSSR, Ser. Khim., 1 (1991) 9 (in Russian).

9. Dubinin M.M., Radushkevich L.V. On the characteristic curve equation for active carbons, Doklady Akademii Nauk SSSR, Ser. Khim., 55 (1947) 331 (in Russian).

10. Dubinin M.M., Astakhov V.A. Development of concepts about the volume filling of micropores for adsorption of gases and vapors by microporous adsorbents. Izvestiya Akademii Nauk SSSR, Ser. Khim., 71 (1971) 5 (in Russian).

11. Dubinin M.M. Physical adsorption of gases and vapors in micropores, Progr. Surf. Membrane Sci. / D.A. Cadenhead, J.F. Danielli, M.D. Rosenberg, Eds. Academic Press, New York, 9 (1975) 1.

12. Dubinin M.M., Stoeckli H.F. Homogeneous and heterogeneous micropore structures in carbonaceous adsorbents, J. Colloid Interface Sci., 75 (1980) 34.

13. Jaroniec M., Madey R. Physical Adsorption on Heterogeneous Solids., Elsevier, Amsterdam, 1988, $351 \mathrm{p}$.

14. Rudziński W., EverettD.H. Adsorption of Gases on Heterogeneous Surfaces, Academic Press, San Diego, 1992, 578 p.

15. Tovbin Yu.K. Molecular theory of spherical drops in the vapor phase, Russ. J. Phys. Chem A. 84 (2010) 1717.

16. Ono S., Kondo S. Molecular theory of surface tension in liquids. "Structure of Liquids /
Struktur der Flüssigkeiten”. Series: Encyclopedia of Physics / Handbuch der Physik, Springer: Berlin, Edited by H.S. Green, Syu Ono, Sohei Kondo and Frank P. Buff, 3/10 (1960) 134.

17. Rowlinson J.S., Widom B. Molecular theory of capillarity, Clarendon, Oxford, 1989, $327 \mathrm{p}$.

18. Antonchenko V.Ya., Davydov A.S., Ilyin V.V. Fundamentals of water physics, Naukova Dumka, Kyiv, 1991, 671 p.(in Russian).

19. Sarman S., Eriksson J.Ch., Kjellander R., Ljungren $S$. Properties of a mean field fluid confined in a narrow slit, Colloid J. USSR, 49 (1987) 217.

20. Everett D.H., Powl J.C. Adsorption in slit-like and cylindrical micropores in the Henry's law region. A model for the microporosity of carbons, J. Chem. Soc. Faraday Trans 1, 72 (1976) 619.

21. Polyakova I.G., Tarasevich Yu.I., Polyakov V.E. Study of the reaction of water vapors with carbon fibers by an adsorption-calorimetric method, Theor. Exp. Chem., 30 (1994) 69.

22. Makhorin K.E., Pishchaj I.Ya. Physicochemical characteristics of carbon sorbents, J. Water Chem. Tech., 18 (1996) 19.

23. Yu.I. Tarasevich, F.D. Ovcharenko Adsorption sur des Minéraux Argileux, Institut Français du Pétrole, Rueil Malmaison, 1980, 449 p.

24. Landau L.D., Lifshitz E.M. Statistical Physics, $2^{\text {nd }}$ Revised and Enlarged Edition, Pergamon, Oxford, 1969, $484 \mathrm{p}$.

Received 29.04.2013, accepted 13.09.13 